MichU

DeptE

ResSIE \#290

\section{RESEARCH SEMINAR IN INTERNATIONAL ECONOMICS}

Department of Economics

The University of Michigan

Ann Arbor, Michigan 48109-1220

SEMINAR DISCUSSION PAPER NO. 270

\title{
Some Economic Effects of Unilateral and Multilateral Reductions in Military Expenditures in the Major Industrialized and Developing Countries
}

by

Jon D. Haveman, Alan V. Deardorff, and Robert M. Stern

Institute of Public Policy Studies

and Department of Economics

The University of Michigan, Ann Arbor

January 1991

\section{Acknowledgements}

This is a revised version of a paper that was presented at the Annual Meeting of the American Economic Association, Conflict and Peace Economics II: Disarmament Effects and National Protection (joint session with the Peace Science Society), Washington, D.C., December 28, 1990.

We are grateful to members of the Research Seminar in International Economics at the University of Michigan, Janet Netz, Peter Pauly, and Kenneth Reinert for their helpful comments on an earlier version of the paper. Financial assistance was provided in part by a grant from the Ford Foundation in support of a program of research in trade policy in the Institute of Public Policy Studies at the University of Michigan.

Address correspondence to:

Robert M. Stern

Institute of Public Policy Studies

The University of Michigan

440 Lorch Hall

611 Tappan Street

Ann Arbor, MI 48109-1220

Telephone: 313-764-2373

Fax: 313-764-2769

SUMNER AND LAURA FOSTER LIBRARY

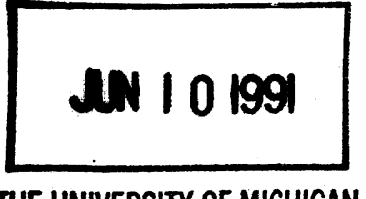





\section{Introduction}

The original impetus for our research was to analyze some of the possible economic effects of a "peace dividend." While the onset of the armed conflict in the Persian Gulf has diverted attention away from the idea of a peace dividend, there is reason to believe, assuming that the conflict will be of short duration, that there will be continuing pressure to reduce and to restructure defense spending. The purpose of our paper is to investigate the possible sectoral impacts on trade and employment in the United States that might be experienced as a result of an across-the-board reduction in military spending. ${ }^{1}$ We do not address the effects of a restructuring of military expenditures.

Using the computational general equilibrium (CGE) Michigan Model of World Production and Trade, we first investigate the impact of a $25 \%$ unilateral reduction in military spending for the United States alone, and subsequently a $25 \%$ multilateral reduction in military spending in all of the major Western industrialized and developing countries. An important advantage in using the Michigan Model is the sectoral detail that it provides. In what follows, we perform a variety of computational experiments that take into account different compensating macroeconomic policies and that enable us to compare the sectoral effects involved. Further, the Michigan Model allows us to extend previous studies by incorporating the effects of international trade and by allowing for price and exchange rate responses as well as primary input substitution possibilities. It is hoped that these additional elements will provide a richer insight into the sectoral effects stemming from possible reductions in military expenditures than has been provided by earlier research. ${ }^{2}$

Previous work has generally compensated for changes in military expenditures

\footnotetext{
${ }^{1}$ As will become clear from the discussion that follows, we can use our modeling framework to analyze increases as well as reductions in military spending.

${ }^{2}$ There may of course be other effects at both the micro and aggregate levels that our modeling approach cannot capture. These effects include the dynamics of adjustment in goods and factor markets and possible impacts working through financial markets and changes in aggregate savings and investment behavior. This suggests the need for a broader and more integrated modeling effort, which is unfortunately something beyond our capability at present.
} 
by changing nonmilitary government purchases. However, as discussed below, prior episodes of substantial reductions in U.S. military expenditures did not follow this path. We therefore assume that reductions in government military spending will be compensated by shifting expenditures to various components of final demand, including: nondefense government spending; private consumption; investment; and a pro rata reallocation across all nondefense sectors.

We proceed as follows. In Section II we present a brief review of previous research. Section III presents a brief description of the Michigan Model and some discussion of elements of it that are of particular importance to our study. Section IV contains an explanation of and results for the unilateral reductions for the United States, while Section V presents the results for the multilateral experiments. We provide some discussion of the implications of the results and conclude in Section VI.

\section{Previous Research}

Over the past 30 years, there have been a number of studies assessing the impact of defense spending on a nation's economy. The pioneer work was done by Leontief and associates in the early 1960s. The results of these studies have been fairly consistent, even though there has been a great deal of variation in methodology and country of analysis. Most studies find that reductions in military expenditures have a positive effect on an economy, in terms of increased employment and, where modelled, increased GNP. The rest of this section will discuss several representative studies.

Leontief and Hoffenberg (1961) used input-output analysis to estimate the impact of a change in military expenditures on employment in 58 broad sectors of the U.S. economy. They analyzed a $20 \%$ reduction in military expenditures coupled with a compensating increase in nonmilitary forms of government spending. The net result was an increase of 288,040 workers in "business employment." This increase stemmed from a transfer of spending, but no reduction in military personnel. The same experiment including a cut in personnel of $20 \%$ yielded a net reduction in employment of 120,758 
workers. They, as do we, also provided results to facilitate the analysis of a shift towards other sectors of final demand, including consumption and investment among others. Their study was, however, performed in a framework with no modelling of international effects, price changes, or substitution possibilities.

Leontief et. al. (1965) was an analysis of the regional impact of a $20 \%$ reduction in military expenditures. This model assumed that final demand adjusts to maintain a constant level of employment in the aggregate U.S. economy. It therefore concentrated on the changing industrial and regional composition of employment.

Dunne and Smith (1984) used the econometrically based Cambridge Growth Project to calculate the impact of military spending on the U.K. economy. Their experiments involved a cut in military expenditures from $5 \%$ of GDP to $3.5 \%$ of GDP, the European average. These cuts were accompanied by matching increases in other forms of government spending. Their general conclusion was that this reduction in military expenditures would increase total employment by approximately 100,000 jobs.

There have been other studies like our own that have employed CGE methods in an international framework. Liew (1985) used the ORANI model of Australia to assess the impact on international trade, prices, and GNP of a $10 \%$ increase in military expenditures. This increase was assumed to be compensated by a reduction in one of three other categories of government spending (i.e., health, education, or welfare), thereby holding total government expenditure constant. Although the results of these three experiments differed somewhat in direction and magnitude, the general message, although quantitatively small in each case, was that an increase in military expenditure would tend to reduce GNP and employment, and create a small merchandise trade deficit. The experiments were consistent in suggesting increased imports, and two of the three experiments suggested a reduction in exports. Liew's results are in line with the other studies mentioned, given the direction of change in military spending. 


\section{Overview of The Michigan Model}

The theoretical structure and equations of the Michigan Model are described in detail in Deardorff and Stern (1986, pp. 9-36 and 235-47; 1990, pp. 9-35). For our purposes here, we present a brief overview of the model and call attention to some of its features that are pertinent to the present analysis.

In designing the Michigan Model, the objective was to take into account as many of the microeconomic interconnections among industries and countries as possible. This disaggregated general equilibrium framẹwork enables us to examine a variety of economic issues that most other computational models cannot address, either because they are too highly aggregated, or because they are specified only in partial equilibrium terms.

\section{Data and Parameters}

The current version of the model includes 22 tradable and 7 nontradable industries in 18 industrialized and 16 developing countries, plus an aggregate sector representing the rest of the world. ${ }^{3}$ We use a base of 1980 data on trade, production, and employment for all 34 countries, plus constructed measures of the coverage of nontariff barriers (NTBs) for the 18 industrialized countries.

\section{Trade, Production, and Employment}

The import and export data are adapted from United Nations trade tapes, with concordances that relate the Standard International Trade Classification (SITC) to our version of the International Standard Industrial Classification (ISIC) categories. Information on the gross value of production and employment by ISIC sector is directly calculated or estimated from United Nations, Yearbook of Industrial Statistics, Organization for Economic Cooperation and Development (OECD) publications on national accounts and labor statistics, and various national statistical sources.

\footnotetext{
${ }^{3}$ The industries are listed in Table 2 and the countries in Table 8.
} 


\section{Nontariff Barriers}

NTBs in the model are represented in two forms: as coverage indices and as tariff equivalents. However, only the coverage indices play a role in the current analysis. These indices measure the degree to which imports are subject to nontariff restrictions. They serve to reflect the role of existing NTBs in dampening the quantitative response of trade when other changes in the economies take place.

\section{Exchange Rates}

In an effort to approximate the functioning of foreign exchange markets, exchange rates are modelled in several different ways. We model the industrialized countries in terms of a flexible exchange rate regime in which exchange rates are determined by the requirement that a country's balance of trade plus an exogenous capital flow be equal to zero. Thus, when an exogenous shock alters the trade balance, the exchange rate is used to restore the trade balance to its initial level. In contrast, most developing countries in the model are assumed to have a system of import licensing with exchange rate pegging. The import licensing scheme in countries with pegged exchange rates is assumed to function in such a way as to assure approximate balance-of-payments equilibrium through a mechanism of proportional rationing of imports.

\section{Input-Output Tables}

Our input-output coverage currently includes national tables for all of the industrialized countries of the model except Switzerland. They are taken from various years ranging from 1975 for Japan and members of the EEC to 1982 for Finland. The 1977 table for the United States is applied to Switzerland. For the developing countries

our coverage currently includes separate tables for Brazil (1975), Chile (1977), Israel (1977), Korea (1980), Portugal (1981), and Spain (1980). The Brazilian table is applied to the remaining developing countries. The use of national tables allows for differences in 
technoiogy among the countries included in the model. ${ }^{4}$

\section{Coefficients and Elasticities}

In general, the coefficients of explanatory variables that appear in the model are calculated from data on production, trade, and employment by sector in each country, from the input-output matrices, and from relevant published estimates of demand and substitution elasticities. The import-demand elasticities used in the model, for all countries, are constructed from the "best guesstimates" of U.S. import-demand elasticities calculated by Stern et al. (1976). Using the import-demand elasticities together with data on trade, we first calculate the implied elasticities of substitution in demand between imported and home-produced goods in each industry of the United States, and we assume that these same substitution elasticities are valid for all other countries. The implicit import-demand elasticities in the other countries are then derived from these common elasticities of substitution, and they differ across countries due to their differences in shares of trade. 5

On the supply side of the model, we use elasticities of substitution between capital and labor in each sector, based upon Zarembka and Chernicoff (1971). These were estimated from U.S. data, but, due to a dearth of estimates for other countries, are assumed to apply for all countries.

\section{The Model Structure}

The model is best thought of as composed of two parts: the country system and the world system. The country system contains separate blocks of equations for the individual tradable and nontradable sectors for each country, and the world system contains a single set of equations for individual tradable sectors for the world as a whole.

\footnotetext{
${ }^{4}$ As will be discussed below, our sector aggregates may obscure technological differences in the production of military and nonmilitary goods in certain sectors.

${ }^{5}$ Use of these elasticities is subject to the limitation that they are valid, at most, only for the range of prices for which they were estimated. This should not be a problem for the results reported here, however, for which individual prices changed in most cases on average by only a few percent.
} 
The country blocks are used first to determine each country's supplies and demands for goods and currencies on world markets, as functions of exogenous variables, world prices and exchange rates. The supply and demand functions for each country are then combined to provide the input to the world system that permits world prices and exchange rates to be determined.

The world system is the less complicated of the two systems. We start with the export supply and import demand functions from the country equations, which depend on world prices and exchange rates. To get world prices, we add these supplies and demands across all countries and set the difference equal to net demand from the rest of the world. To obtain exchange rates, where these are flexible, we add the value of excess supply across all of the industries in a country and equate the resulting trade balance to an exogenously given capital flow. Once we obtain the world prices for each tradable industry and the exchange rate for each country, we enter them back into the separate country blocks in order to determine the rest of the relevant country-specific variables.

\section{Description of the Exogenous Change Variables}

The Michigan Model can be used to analyze price and quantity responses to a number of exogenous changes in the world trading environment. These changes can be represented through the use of some 18 exogenous variables, each referring to a different change in the trading environment. These variables include, for example, changes in import tariffs, changes in export taxes, changes in exchange rates where they are exogenous, and changes in the aforementioned capital flows.

For the current analysis, however, we use only two exogenous change variables, both representing particular kinds of shifts in demand. One is an inter-industry shift variable, denoted e $\alpha$, that describes a reallocation of final demand across industries. The other is an intra-industry shift variable, denoted $\mathrm{e} \beta$, that captures a shift of demand within an industry from home-produced goods to imports. Since neither of these variables has been described explicitly in earlier work on the Michigan Model, we present here a 
brief formal statement of the roles that these two shift parameters play.

The demand shift parameters operate through the consumption side of the model, which consists of a representative consumer in each country. The consumer (representing all final demand) maximizes utility, $\mathrm{U}$, derived from the consumption of home-produced goods, $\mathrm{C}_{\mathrm{j}}^{\mathrm{H}}$, and of imports, $\mathrm{C}_{\mathrm{j}}^{\mathrm{M}}$, subject to the constraint of a given level of expenditure, E. We assume that the utility function is weakly separable into a CobbDouglas function whose arguments for each industry are themselves linearly homogeneous functions of home and import consumption in that industry. Let $\alpha_{j}, j=1, . ., n$, with $\sum_{j=1}^{n} \alpha_{j}=1$, be the parameters of the Cobb-Douglas function. Then final demand is the solution to the following maximization problem:

$$
\begin{aligned}
& \underset{j=1}{\operatorname{maximize} U}=\prod_{j}^{n}\left[A^{j}\left(C_{j}^{H}, C_{j}^{M}, \beta_{j}\right)\right]_{j}^{\alpha_{j}} \\
& \text { subject to } \sum_{j=1}^{n}\left[\mathbf{p}_{j} C_{j}^{H}+\mathbf{p}_{j}^{M} C_{j}^{M}\right]=E
\end{aligned}
$$

where $\mathrm{n}$ is the number of goods. ${ }^{6}$ The intra-industry shift parameters, $\beta_{\mathrm{j}}$, enter the home-import industry aggregation functions, $A^{j}$, in a manner that will be specified below.

First order conditions for this problem are

$$
\alpha \frac{\mathrm{UA}_{\mathrm{M}}^{\mathrm{j}}}{\mathrm{A}^{\mathrm{j}}}=\lambda \mathrm{p}_{\mathrm{j}}^{\mathrm{M}}
$$

$$
\mathrm{j}=1, . ., \mathrm{n}
$$

\footnotetext{
${ }^{6}$ We do not make a distinction here between traded and nontraded sectors.
} 


$$
\alpha \frac{\mathrm{UA}_{\mathrm{H}}^{\mathrm{j}}}{\mathrm{A}^{\mathrm{j}}}=\lambda \mathrm{p}_{\mathrm{j}}^{\mathrm{H}}
$$

$$
\mathrm{j}=1, . ., \mathrm{n}
$$

where $\lambda$ is the Lagrange multiplier. From (2)-(4) and the homogeneity of $\mathrm{A}^{\mathrm{j}}$, it can be shown that

$$
\frac{\mathrm{U}}{\lambda}=\mathrm{E}
$$

We now proportionally differentiate the system (3) and (4) using the notation that, for any variable $x, e x=d(\ln x)=d x / x$. When we also substitute in for $\lambda$ from (5), we obtain the following differentiated functions:

$$
\begin{gathered}
e \alpha_{j}+e E+e A_{M}^{j}-e A^{j}=e p j_{j}^{M}, \\
e \alpha_{j}+e E+e A_{H}^{j}-e A^{j}=e p{ }_{j}^{H} .
\end{gathered}
$$

The e $\alpha_{j}$ terms in the above equations represent proportional shifts in the demands for each of the $\mathrm{n}$ industries, and they play the role of the inter-industry shift parameters mentioned above. Since the $\alpha_{j}$ are constrained to sum to one, these shift parameters must also satisfy the following constraint:

$$
\sum_{j=1}^{n} \alpha_{j} \text { e } \alpha_{j}=1
$$

Using the first order conditions it can be seen that $e A_{M}^{j}-e A_{H}^{j}=e p_{j}^{M}-$ $\operatorname{ap}_{j} \mathrm{H}$. If we define $\sigma_{j}$ to be the elasticity of substitution between home and imported goods, $\sigma_{\mathrm{j}}$ is then given implicitly by the following equation: 


$$
\mathrm{eC}_{\mathrm{j}}^{\mathrm{H}}-\mathrm{eC}_{\mathrm{j}}^{\mathrm{M}}=\sigma_{\mathrm{j}}\left[\mathrm{ep_{j } ^ { \mathrm { M } }}-\mathrm{ep_{j }} \mathrm{H}^{\mathrm{H}}\right]+\left(1 / \theta_{\mathrm{H}}^{\mathrm{j}} \mathrm{e} \beta_{\mathrm{j}}\right.
$$

where we have also included a particular role for the intra-industry shift parameter, whose proportional change is given as $\mathrm{e} \beta_{\mathrm{j}}$. Its coefficient $\left(1 / \theta_{\mathrm{H}}^{\mathrm{j}}\right)$, as will be seen below, is present to provide a simple interpretation of this shift parameter.

Combining (3') and (4') with equations (5) and (7), it is straightforward to derive the following differentiated demand functions:

$$
\begin{aligned}
& \mathrm{eC}_{\mathrm{j}}^{\mathrm{H}}=\mathrm{eE}+\mathrm{e} \alpha_{\mathrm{j}}-\left(\theta_{\mathrm{M}^{\mathrm{j}}}^{\mathrm{j}} \mathrm{H}_{\mathrm{H}}^{\mathrm{j}}\right) \beta_{\mathrm{j}}
\end{aligned}
$$

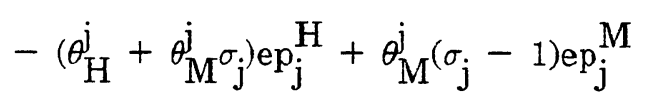

$$
\begin{aligned}
& \mathrm{eC}_{\mathrm{j}}^{\mathrm{M}}=\mathrm{eE}+\mathrm{e} \alpha_{\mathrm{j}}+\mathrm{e} \beta_{\mathrm{j}} \\
& -\left(\theta_{M}^{j}+\theta_{H_{j}^{j}}^{\left.\sigma_{j}\right) e p_{j}^{M}}+\theta_{H^{j}}^{\left(\sigma_{j}\right.}-1\right) e_{j}^{H}
\end{aligned}
$$$$
\mathrm{j}=1, \ldots, \mathrm{n},
$$

Here $\theta_{M}^{j}$ and $\theta_{H}^{j}$ are defined as the shares of imports and home goods, respectively, in the final demand for good $\mathrm{j}^{7}$

The intra-industry shift parameter, $\mathrm{e} \beta_{\mathbf{j}}$, has been defined so that it enters with a coefficient of unity in the equation for the proportional change in imports, $\mathrm{eC}_{\mathrm{j}}^{\mathrm{M}}$. Thus e $\beta_{\mathrm{j}}$ represents the shift toward imports in industry $j$, measured as a proportion of initial imports in that industry. ${ }^{8}$

\section{U.S. Unilateral Reductions in Military Expenditures}

In this section, we consider the effects of a $25 \%$ unilateral reduction in military

\footnotetext{
${ }^{7} \theta_{\mathrm{H}}^{\mathrm{j}}$ is therefore equal to $1-\theta_{\mathrm{M}}^{\mathrm{j}}$.
}

${ }^{8}$ The variable that actually enters the Michigan Model is the negative of this, because it was originally
intended to capture the effects of a government procurement regulation that shifts a portion of import
demand to the home sector. 
expenditures in the United States and discuss the implications of different assumptions regarding the macroeconomic policies accompanying such a reduction. The effects of a multilateral $25 \%$ reduction in military expenditures simultaneously in all of the major Western industrialized and developing countries included in the Michigan Model are considered in the following section. The results presented in this section are intended to facilitate the analysis of a broad spectrum of scenarios concerning the macroeconomic policies accompanying a reduction in U.S. military expenditures. We first provide some background of previous periods of reduced defense spending and then a description of the assumptions and theoretical implementation of the scenarios within the Michigan Model. The results of the various scenarios are presented at the end of this section.

Substantial reductions in defense spending are not new to the United States [Steuerle \& Wiener (1990)]. The periods immediately following World War II, the Korean conflict, and the Vietnam War each saw a substantial de-emphasis of defense spending within the government budget and as a share of GNP. The immediate post-WWII years represent the largest decline, when defense spending fell from $39.1 \%$ to $3.7 \%$ of GNP between 1945 and 1948. The five years following the Korean and Vietnam wars each saw defense spending decline, but by the more modest amount, in both cases, of approximately $4 \%$ of GNP.

In periods of substantial restructuring of government spending, the question naturally arising is what happens to nonmilitary expenditures when military expenditures are reduced. There are principally three macroeconomic policies that could accompany a reduction in military expenditures: (1) increase other spending; (2) reduce taxes; or (3) reduce government borrowing. That is, first, policy makers could redistribute the expenditure to other forms of government spending such as human or physical resources. Second, the reduction in expenditure could be matched by a reduction in government receipts, thus increasing civilian consumption. Finally, the reduced expenditure could be used to reduce (increase) a budget deficit (surplus), reducing interest rates, and thereby 
stimulating investment. The three postwar periods experienced each of these policies, but in rather different combinations.

Table 1 provides a detailed account of the macroeconomic policies accompanying the demilitarization in each of the three periods noted above and the present period of reduced defense expenditures. Column 1 shows the change in defense spending, while columns 2-4 display the accompanying changes in the other major components of the government budget. From column 4, it can be seen that each period is associated with falling budget deficits. In each of the postwar periods, $30 \%$ or more of the reduction in military spending was used to reduce the budget deficit. In the current period, the decline in the deficit exceeds the reduction in military spending.

In the immediate post-WWII and post-Korean conflict years, a significant portion of the reduced defense spending was used to offset federal government receipts, as displayed in column 3. The latter two time periods have, however, been associated respectively with a zero and positive change in receipts, as a percent of GNP. The propensity for shifting expenditure from defense to human resources increased throughout the first three periods, while the current demilitarization is accompanied by a fall in human resources spending. 9

As Steuerle and Wiener note, the late-Reagan-early-Bush era of reduced defense spending is rather uncharacteristic. The period from 1986 to 1989 witnessed a reduction in defense spending, as a percent of GNP, a reduction in spending on human resources, an increase in total revenue, and a reduction in the deficit of almost four times the reduction in defense spending. The uncharacteristic nature of this period is not surprising given that this is the first large-scale peace-time demilitarization.

It is evident from these experiences that there have been a variety of macroeconomic responses to reductions in military expenditures. This makes it difficult to

\footnotetext{
${ }^{9}$ Human resources include spending on health and Medicare, income maintenance, Social Security, and education programs.
} 
determine what the appropriate strategy should be in modelling such expenditure reductions. The effect on the sectoral composition of trade and employment due to a reduction in defense spending depends crucially on the assumptions one makes about the accompanying macroeconomic policies. Since the Michigan Model does not formally allow for changes in interest rates or domestic taxes, the individual scenarios are implemented by exogenously altering the composition of final demand. In what follows, we make allowances accordingly for shifts in defense spending to several categories of final demand, including consumption, investment, nonmilitary government spending, and a pro rata shift across all sectors of nonmilitary final demand. We then examine separately the results of each shift.

\section{Computational Experiments and Assumptions}

We shall concentrate on the four scenarios just mentioned. Each scenario is based on an alternative redistribution of $\$ 64.8$ billion in military expenditures, or $25 \%$ of the 1985 U.S. national defense budget. ${ }^{10}$ This reduction is taken as a uniform percentage of the defense budget allocated to each of the 29 sectors being modelled. In the first scenario, the reduction in military spending is assumed to be absorbed proportionally by all three sectors of final demand: consumption; investment; and nonmilitary government expenditure. The second scenario redistributes spending from defense to other forms of government expenditure, maintaining constant levels of consumption and investment. The third scenario redistributes the spending across consumption while keeping other sources of final demand constant, and the fourth redistributes the spending across investment ${ }^{11}$ while, again, maintaining a constant level of consumption and nonmilitary government purchases. In all runs, the $\$ 64.8$ billion is allocated to each sector according to that

\footnotetext{
${ }^{10}$ The use of a 1985 sectoral breakdown in military expenditures reflects the availability of the most recent input-output table for the United States. In performing the experiments we use the more disaggregated 1977 input-output table to represent technology. It is assumed that the technology represented there still holds for 1985.

${ }^{11}$ Investment is taken to be only gross private fixed investment. Changes in business inventories are considered to be of a more transitional nature and less sensitive to interest rate fluctuations, and hence not affected by a reduction in the budget deficit.
} 
sector's share in demand. ${ }^{12}$ While we do not suggest that any one of these experiments captures exactly what is likely happen, the linear nature of the model allows one to approximate any in-between cases.

In interpreting the results to follow, it is important to note the assumptions that are common to all scenarios:

(1) The level of aggregate expenditure is constant.

(2) Capital stocks are fixed for each industry, on the grounds that the time period under investigation is too short for changes in investment to be realized as additions to the capital stock.

(3) Real wages are assumed to be flexible, i.e., labor markets are permitted to clear.

(4) The U.S. Department of Defense is assumed to follow a "buy American" policy. All defense expenditure is assumed to have been allocated to domestic industry.

(5) Exchange rates are modeled as flexible, except for a number of developing countries.

Some of these assumptions are in need of further explanation or justification.

First, the assumption that aggregate expenditure is held constant is necessary because the microeconomic orientation of the Michigan Model makes it inappropriate for discussing macroeconomic phenomena such as the determination of aggregate expenditure or employment. Implicit within this assumption, and the form of each scenario, is that a dollar-for-dollar transfer is made. For example, with a reduction in the budget deficit it is assumed that investment changes by exactly the amount of the change in the deficit. Further effects of the changed interest rate would likely be changes in consumers' savingsconsumption choices. Such effects are not represented explicitly in the Michigan Model.

A further consequence of the microeconomic nature of the model is assumption (3). Our results are all dependent on constant aggregate employment, which is assured by allowing for flexibility in real wages. There are alternative methods of maintaining

\footnotetext{
${ }^{12}$ For example, in scenario 3 , suppose sector 310 is $10 \%$ of total civilian demand. Then spending in sector 310 is assumed to increase by $\$ 6.48$ billion. Similarly in scenario 3 , if sector 310 is $10 \%$ of consumption, spending in sector 310 increases by $\$ 6.48$ billion.
} 
constant employment, such as allowing the composition of final demand to adjust appropriately, but these adjustments would de-emphasize the role played by the differences in the distribution of military spending and the distribution of other sources of final demand.

Assumption (4), representing the "buy American" or "buy domestic" policy of the U.S. Department of Defense (DOD), is designed to reflect the preference given to domestic manufacturers and suppliers when contracts are signed and purchases are made. Given this preference, we believe that the average propensity of the DOD to import is significantly less than that of final and intermediate demand in the aggregate. Zero imports are thus assumed to be a more accurate representation of reality than is the aggregate average propensity to import.

Implementation of the policy experiments is conceptualized as a shift in the final demand for the output of each of the 29 sectors. The first step in each of the scenarios is to redistribute the reduction in military spending appropriately. Table 2 reports actual 1985 levels of consumption, investment, government nondefense, and defense spending. Table 3 shows the sectoral changes in demand brought about by each of the above scenarios. These redistributions of final demand are represented as changes in the demand share parameters of the consumers' utility function. In what follows, $\alpha_{j}$ will be used to represent the share of final demand attributable to purchases from sector $j$. Given the nature of the model, the proportional change in these parameters is needed to reflect the shift in final demand. The proportional change variable is obtained by calculating the actual share of each sector in final demand $\left(\alpha_{o j}, j=1, . ., 29\right)$ and the final demand share of each sector once the defense spending has been redistributed $\left(\alpha_{1 j}, j=\right.$ 1,..,29). The proportional change is then calculated as:

$$
\mathrm{e} \alpha_{\mathrm{j}}=\frac{\mathrm{d} \alpha}{\alpha}=\frac{\alpha_{1 \mathrm{j}}-\alpha_{\mathrm{oj}}}{\alpha_{\mathrm{oj}}}, \quad \mathrm{j}=1, \ldots, 29
$$


As noted above, defense purchases are assumed to be made entirely from domestic production. The shift of expenditure away from defense will therefore be accompanied by an exogenous increase in imports. As a result, we need to adjust the fraction of new expenditure that now goes towards the purchase of imported goods. We assume that each category of total demand in an industry purchases imports in the same percentages as that of final demand in that industry as a whole. More precise estimates could be made if a breakdown of imports by consumption, investment, and government purchases could be used, but unfortunately, such data are not available.

Tables $4 \mathrm{a}$ and $4 \mathrm{~b}$ present a simple hypothetical example that is intended to clarify the process outlined above. Columns 1 and 2 of each table represent the part of final demand made up of defense and all other final demand respectively. Column 3 is total final demand, and column 4 is the $\alpha$, or share of each sector in total final demand, from equation 1 . Table $4 \mathrm{~b}$ shows what happens to final demand and demand shares when $\$ 150$ million, or $25 \%$, of defense spending is shifted to other final demand.

The process begins by reducing the value of defense in each cell by $25 \%$. Thus, column 1 in Table $4 \mathrm{~b}$ is $75 \%$ of column 1 in Table $4 \mathrm{a}$. This $\$ 150$ million is then redistributed across other final demand in proportion to each sector's share in total other demand. For example, other final demand in sector 1 is $50 \%$ of total other demand and, therefore, increases by $\$ 75$ million, $50 \%$ of the reduction in military spending. As can be seen from column 4 of each table, the redistribution causes the $\alpha$ s to change significantly. As discussed above, the proportional changes, eas, are needed for carrying out the experiments. For sector 1 , we have:

$$
\mathrm{e} \alpha=\frac{.38-.33}{.33}=.15 \text {. }
$$

The other changes in shares are calculated analogously.

It is also convenient to use Table 4 to illustrate the exogenous change in imports discussed above. In sector 1, for example, other final demand increases by $\$ 75$ 
million. If $10 \%$ of all demand, both intermediate and final, in sector 1 is imported, the imports of sector 1 commodities are assumed to increase by $10 \%$ of the increase in other final demand, which is $\$ 7.5$ million in this case. Similarly, in sector 2 , nonmilitary final demand increases by $\$ 25$ million. If $20 \%$ of all demand in sector 2 is imported, imports of sector 2 commodities increase exogenously by $\$ 5$ million.

\section{Some Theoretical Considerations}

Before looking at the computational results of our experiments, it is useful to examine what one would expect in terms of a simple theoretical model that captures some, though by no means all, of the interactions that are present in the Michigan Model. This can be done with the aid of the (partial equilibrium) supply and demand diagrams shown in Figure 1.

The top panel of Figure 1 shows the market for home-produced goods in a representative industry. Supply and demand in such a home market depend of course on the home price, but the positions of the supply and demand curves also depend on various prices of imports. This dependence is only shown in the figure for the price of the imported good in the same industry. This matters for demand because of consumer substitution, and it matters for supply because of the use of imports as inputs into production.

The bottom panel shows the markets for exports and imports within the same industry. Here the prices and quantities of exports and imports are drawn for convenience on the same axis, because in the model they are viewed as identical products in the world market. However, within the country imports of an industry are viewed as distinct from exports, and there is no reason in general to compare them. Nonetheless, we show them being equal initially, partly for convenience and partly to enable us, even though inappropriately, to represent the process of exchange rate adjustment in this single market context.

For both exports and imports the world price in the industry, $\mathrm{P}_{\mathrm{W}}$, is translated into domestic currency by multiplying by the exchange rate, $R$. In the absence of any 
export taxes or subsidies, this gives the export price, $\mathrm{P}_{\mathrm{X}}$. The suppiy of exports depends upon this price, as well as the price in the home market, again because of the use of home market goods as inputs into production for export. ${ }^{13}$

The price facing importers, $\mathrm{P}_{\mathrm{M}}$, is also given by $\mathrm{RP}_{\mathrm{W}}$, except that it is augmented by $t$, representing the ad valorem tariff together with the tariff equivalent of any nontariff barrier that may be present. Thus the demand curve is drawn as a function of $\mathrm{P}_{\mathrm{M}}$, as well as, again, having its position depend on the home price from the other panel.

A cut in defense expenditure has two effects, as already noted. First, depending upon where defense expenditure was concentrated compared to the pattern of expenditure in the category of final demand to which that expenditure is shifted, total demand in some industries will rise and in other industries will fall. We will look at both cases in turn. Second, even in industries where total demand declines, and certainly in ones where demand expands, there is a shift from defense spending, which was devoted exclusively to home goods, to other demand that is spent partly on imports. This means that there is an additional leftward shift of the home-sector demand curve and a rightward shift of the import demand curve.

Consider, then, an industry in which there has been no defense spending. The cut in defense spending will therefore, at initial prices, unambiguously increase total demand in that industry, as well as increasing demands for both imported and home produced goods there. This is shown in Figure 2 by the shifts of the two demand curves to $\mathrm{D}_{\mathrm{H}}^{1}\left(\mathrm{P}_{\mathrm{M}}^{0}\right)$ and $\mathrm{D}_{\mathrm{M}}^{1}\left(\mathrm{P}_{\mathrm{H}}^{0}\right)$. As long as the world price and the exchange rate do not change, the prices of exports and imports in the sector will remain constant. However, the shift in demand in the home sector requires a price increase there, to $\mathrm{P}_{\mathrm{H}}^{1}$, and this induces a further shift in both supply and demand for exports and imports. The demand for imports

\footnotetext{
${ }^{13}$ Of course inputs from other sectors are typically more important than inputs from the same industry represented here. Other than this input-price effect, the Michigan Model does not include any direct effect of the home price on export supply, or vice versa, since capital is assumed specific to each subsector and labor can be hired independently in each.
} 
shifts further to the right, to $\mathrm{D}_{\mathrm{M}^{1}}^{1}\left(\mathrm{P}_{\mathrm{H}}^{1}\right)$, due to substitution away from higher priced home goods. And the supply of exports shifts to the left, to $\mathrm{S}_{\mathrm{X}}\left(\mathbf{P}_{\mathbf{H}}^{1}\right)$, due to the higher prices of inputs from the home sector. Thus the result at this point is a rise in output in the home sector, a fall in exports, and a rise in imports.

These results could change somewhat, however, if there is a change in prices of exports and imports, though this is not shown in the diagram. If the country is large in the world market, then its increased net demand for imports will raise the world price, $\mathrm{P}_{\mathrm{W}}$. In addition, if the increase in net imports here applies to other industries as well, then the worsening of the trade balance will lead to a depreciation of the currency, that is a rise in $\mathrm{R}$, which will also raise the domestic currency prices of traded goods. On the export side, a price increase for either of these reasons will tend to offset the decline in exports shown in Figure 2, and may even lead exports in certain sectors to increase overall.

On the import side, the possible price increase for these two reasons may in addition be enhanced by still another possibility. If the industry being considered is covered by a nontariff barrier, then the attempt to increase imports will lead to a rise in the tariff equivalent of the barrier, and thus to a rise in $t$, raising the price of imports still further. Thus for three reasons $\mathrm{P}_{\mathrm{M}}$ may rise, and if it does the changes in Figure 2 will be further complicated. Such a rise in $\mathrm{P}_{\mathrm{M}}$ will lead to a further upward shift in $\mathrm{D}_{\mathrm{H}}$, plus an upward shift in $\mathrm{S}_{\mathrm{H}}$, possibly changing the quantity in the home market from that shown in Figure 2, and surely increasing the price there still further. The additional price increase will also lead to further shifts of supply and demand for trade, and so on. The end result can therefore not be obtained with certainty from the diagram. However, all of these secondary shifts seem unlikely to change in a substantial way the results that are shown in Figure 2, which may therefore still be of use in understanding the results of the more complicated interactions captured by the Michigan Model.

Figure 3 shows the opposite extreme case, where defense expenditure in an 
industry is cut substantially and only a small amount of new final demand is created in the same industry, thus reducing total demand. The demand curve in the home sector therefore shifts to the left, to $\mathrm{D}_{\mathrm{H}}^{1}\left(\mathrm{P}_{\mathrm{M}}^{0}\right)$, while the demand curve for imports shifts slightly to the right, to $\mathrm{D}_{\mathrm{M}}^{1}\left(\mathrm{P}_{\mathrm{H}}^{0}\right)$. The price in the home market therefore falls in this case, to $\mathrm{P}_{\mathrm{H}}^{1}$, and this shifts both the supply of exports and the demand for imports down. The results, therefore, are a rise in exports and a fall in imports (assuming, as shown, that the initial increase in import demand is small compared to the effect of the drop in the home price).

Here again, there could be further adjustment of prices if there are changes in world prices, the exchange rate, or the tariff equivalent of a nontariff barrier, and in this case the effects would tend to go in the opposite direction from what we discussed in connection with Figure 2. However, since over the entire economy the defense cut replaces spending that was only in home sectors with other spending that goes partly to imports, the case of an exchange rate depreciation that was considered there seems the much more likely one.

To sum up, our theoretical analysis suggests that home-sector prices will rise in some sectors and fall in others due to a shift of expenditure out of defense, with corresponding changes in home-sector outputs. As a first approximation, imports rise and exports fall in sectors where demand expands, while the opposite is likely where demand contracts. However, because of the overall shift toward imports with the cut in defense, the currency is likely to depreciate, and this tends to raise prices across the board.

\section{Computational Results}

The Michigan CGE model produces results for a wide range of endogenous variables that emerge from the calculations as percentage changes for each of the 29 sectors. Base year data, 1980 in this study, are then used to compute absolute changes for selected variables, e.g., exports, imports, and employment. In what follows we discuss all four scenarios, but emphasize the results of the first experiment, that of a shift from defense to all other sources of final demand. The other three scenarios will be discussed 
subsequently.

\section{Scenario 1: Redistributing Spending Across Total Final Demand}

The aggregate results for the United States for each of the four scenarios are presented in Table 5 . Column 1 of Table 5 refers to the results of redistributing spending across Total Civilian Demand, i.e., consumption, investment and nonmilitary government spending combined. It appears that a $25 \%$ reduction in defense spending is fairly painless in the aggregate. That is, there is a marginal reduction in both exports and imports, ${ }^{14}$ and only $0.6 \%$ of the US labor force would experience some dislocation.

The reduction in U.S. exports is not surprising. Column 1 of Table 2 shows domestic demand increasing in a majority of the tradable sectors. This increase in demand will cause an increase in the home price for that industry, leading to a substitution from production for export to production for home use, thus reducing total exports. The change in aggregate imports is somewhat less intuitive. Recall that defense expenditure is assumed to be spent entirely in home sectors and that the shift of expenditure therefore involves an exogenous increase in imports. Given this assumption, it is somewhat surprising that imports decline in the aggregate. One possible explanation is that the fall in the home price for a sector experiencing a reduction in demand is large enough to cause sufficient substitution away from imports in that sector so as to overwhelm the exogenously imposed increase. We will demonstrate in what follows that this is indeed what is happening.

The results discussed thus far are aggregates of the changes that take place in the underlying sectors of the U.S. economy. It is also of interest to analyze the sectoral breakdown of exports, imports, and employment. Tables 6 and 7 contain the sectoral results for the four experiments. Again, looking at the first scenario, it does not appear that any one industry will be seriously impacted.

\footnotetext{
${ }^{14}$ Other experiments in which no "buy American" policy for defense is assumed yield similar but slightly stronger impacts on imports and exports.
} 
Basic metal industries (371 and 372), durable goods sectors $(381,382,383$, 384, and 38A) and community, social and personal services (ISIC 9, which includes government employment) are the only sectors in which employment decreases significantly in percentage terms, as can be seen in partition 1 of Table 6 . Only three sectors experience a significant decline in absolute employment. Employment in ISIC 9 falls by 329 thousand person-years, which is $1.0 \%$ of that sector's 1980 employment. Electric machinery (ISIC 383) and transport equipment (ISIC 384) each fall by roughly $2.8 \%$, or 63 and 64 thousand person-years, respectively.

The aggregate figures for the change in imports, it turns out, tell a very misleading story, as can be seen in partition 1 of Table 7 . While imports fall in the aggregate, at the sectoral level imports actually rise, as expected, in all but a handful of sectors. It can be seen by comparing column 1 of Table 3 with partition 1 of Table 7 that all sectors in which imports decline had a decrease in domestic demand. For two sectors in which demand falls, miscellaneous manufacturing (38A) and nonelectric machinery (382), the exogenous increases in imports are enough to outweigh the substitution effect resulting from the reduced home price. As a result, they each experience an increase in imports. This is the case for 16 of the 22 sectors modeled. Of the six remaining sectors experiencing a reduction in demand, five show a negligible decline in imports. The sixth, transport equipment (384), shows a decline of 4.4 percent or $\$ 1.4$ billion. The decline in this sector alone is enough to offset the combined increase in the other sectors.

The sectoral changes in exports are much less surprising. As can be seen from partition 1 of Table 6, 19 of the tradable sectors experience a small decline in exports, with leather products (323) experiencing the largest decline in percentage terms, $1.6 \%$, while the value of exports in food, beverage, and tobacco (310) declines the most, $\$ 190$ million. The response of these sectors is consistent with the intuition described above. The remaining three sectors, agriculture (1), footwear (324), and electrical machinery (382), each produce more for export once expenditures are redistributed. Intuition would suggest 
that exports should increase in sectors experiencing a decrease in domestic demand. As noted above, this increase is a result of the fall in the home price. However, this only happens in one of the seven traded sectors in which domestic demand falls. In six of these sectors, the appreciation of the currency ( $a$ fall in $R$ in the diagrams) combined with a fall in the world price is sufficient to offset the effects of the fall in the home price.

\section{Scenario 2: Redistributing Spending Across Nondefense Government Spending}

The second scenario again reduces military expenditures by $25 \%$, but includes a compensating policy of increasing only nondefense related government spending. In the aggregate, the employment effects of this alternative redistribution are not qualitatively different. This more directed distribution does, however, impact the traded sectors to a much larger extent than does the previous scenario. Exports fall by $\$ 1,197.9$ million, three times the fall in scenario 1 , and imports fall by $\$ 912.0$ million, more than five times the reduction in scenario 1 .

At the sectoral level, from partition 2 of Table 6, we can make several general comments regarding the employment changes. First, the burden of such a reduction appears to fall disproportionately on the traded sectors. There is a net transfer of 294.8 thousand person-years from traded industries to nontraded industries. ISIC 9 appears to be driving this shift. These results reflect the larger fraction of nondefense government purchases that come from nontraded industries. ${ }^{15}$ Second, it should be noted that the burden borne by the traded industries is heavier and more evenly distributed across industries than in scenario 1.

The sectoral impact on exports is more evenly distributed than previously and of a larger magnitude in each industry. The aggregate reduction in imports remains concentrated in the durable goods industries and is, again, largely due to the disproportionately large reduction in demand for goods produced by the transportation

\footnotetext{
${ }^{15}$ Recall that the assumption regarding defense purchases was that, within industries, defense purchases were disproportionately from home suppliers. That a greater proportion of defense spending is from traded sectors is consistent with this assumption.
} 
equipment industry (384).

\section{Scenario 3: Redistributing Spending Across Consumption}

The results of the third scenario reflect a shift in spending from defense to consumption. This shift is intended to represent a reduction in taxes as a response to reduced military expenditures.

The aggregate results in Table 5 are once again larger than those reported for scenario 1. The effect on employment is a dislocation of 734.5 thousand workers. The impact on imports and exports is less severe than scenario 2, but still larger than for the shift in scenario 1. Imports and exports each fall by $0.4 \%$, or $\$ 663.5$ million and $\$ 887.8$ million, respectively.

This restructuring of final demand shows a slightly weaker impact on traded goods than did the previous scenario. As reported in Table 6, there is a shift of 177.4 thousand person-years from traded to nontraded industries. This is, again, a reflection of the higher propensity of consumers to purchase nontraded goods relative to that of the DOD. Private consumers place a much greater emphasis on purchases from wholesale and retail trade (6), and finance, insurance, and real estate (8) than does the DOD. Partition 3 of Table 6 shows that employment in wholesale and retail trade (6), and finance, insurance, and real estate (8) increase significantly, while workers in the durable goods industries $(381,382,383,384$, and 38A) and sector 9 bear the brunt of the dislocations.

The sectoral impact on exports is uniformly negative, reflecting the currency appreciation and increased demand in most sectors. The impact on imports conforms to a priori expectations. In sectors where demand increases, imports increase and, conversely, imports fall in sectors with decreasing demand.

\section{Scenario 4: Redistributing Spending Across Private Fixed Investment}

The final unilateral scenario is a shift in spending to private fixed investment. This scenario is intended to mimic a reduction in the budget deficit accompanying a 
reduction in military expenditures. The reduced budget deficit presumably causes interest rates to fall and consequently encourages private fixed investment. The results for this scenario are strikingly different from the preceding ones. The increase in investment demands leads to an increase in both exports and imports. The number of worker dislocations is also largest for this type of a shift. It is interesting to note, from partition 4 of Table 3, that demand increases significantly in only four sectors: furniture and fixtures (332), nonelectric machinery (382), construction (5), and wholesale and retail trade (6). This is due to the high level of concentration of investment expenditures. The expenditure in these four sectors is significantly greater than that of the remaining sectors.

The sectoral results present a very interesting picture. Partition 4 of Table 6 indicates that employment increases in 17 of the 22 traded sectors. This happens despite a decline in demand for 20 of the traded sectors. There is also a net transfer of 196.9 thousand person-years from the nontraded sectors to the traded sectors.

The phenomenon of increasing employment accompanying decreasing domestic demand can be explained by the resulting change in exports, noted in partition 4 of Table 7. The declining domestic demand, resulting in a lower home price for the good, combined with a depreciation of the dollar leads to an increase in exports in all sectors, with the exception of wood products (331). This increase in exports is in most cases sufficient to offset the employment effects of the reduced domestic demand.

The sectoral effects on imports are driven, to a large extent, by the exogenous increase caused by the shift away from defense purchases. Sectors not receiving an exogenous increase in imports generally experience a decline and, conversely, those with an exogenous increase generally experience increased imports. ${ }^{16}$

\section{Summary}

The results of the first three scenarios are qualitatively similar while the fourth

\footnotetext{
${ }^{16}$ Recall that industries with positive investment purchases will receive an exogenous increase in imports, while those with no investment demand do not.
} 
is significantly different from the others. The first three scenarios suggest that the burden of shifting expenditures is disproportionately borne by the traded goods industries, while the fourth shifts the burden to nontraded industries. The linear nature of the model is reflected in the first scenario, which is a weighted average of the other three.

It should be noted in all the scenarios that military personnel are included in sector 9, which means that we assume the military employs workers in the same proportion as all other components of sector 9. The results presented above will thus under- or overstate the results according to the difference in labor as a fraction of spending in each component of sector 9. Nonetheless, correction for these inaccuracies would not change the qualitative nature of the results.

\section{Multilateral Reductions in Military Expenditure}

In this section, we present the results of an experiment similar to scenario 1 above. This experiment involves a pro rata shift of $25 \%$ of 1985 military expenditures across all categories of final demand for 33 of the 34 countries included in the model. ${ }^{17}$ The assumption that military expenditures in most countries are biased towards home produced goods is less applicable in many countries than it is for the United States. Countries such as Australia simply do not possess the necessary industry to satisfy the demands of its government's military. The "buy domestic" assumption is, therefore, assumed to hold only for the United States.

In order to calculate the demand shift parameters for each of the 29 industries in each country, it was necessary to distribute the aggregate military expenditure and GNP data obtained across the industries modelled. ${ }^{18}$ The distribution of GNP was accomplished through the use of the input-output tables already employed in the model.

\footnotetext{
${ }^{17}$ Data for Hong Kong are not available, so there is assumed to be no shift in demand within Hong Kong.

${ }^{18}$ Data on aggregate military expenditures and gross national product for each country for 1985 were obtained from the U.S. Arms Control and Disarmament Agency (ACDA) publication, World Military Expenditures and Arms Transfers, 1987 edition. In some cases, the most recent available data were for 1984.
} 
The aggregate obtained was distributed to replicate the share in final demand for each of the 29 sectors.

Leontief and Duchin (1983) provide estimates of the proportion of the ACDA data on aggregate military expenditures that correspond to 12 categories. We in turn concorded these categories to our industrial classification. They also provide estimates of the decomposition of the ACDA data by sector for 15 regions of the world. We used these regional breakdowns for each of the 33 countries to correspond to their location within the individual regions. ${ }^{19}$

\section{Computational Results}

The summary results for the United States of the multilateral $25 \%$ reduction in military expenditures are presented in Table 8. The effects on other countries will be addressed in future work. For comparison with the other experiments, the aggregate results for the United States are also listed in column 5 of Table 5 . The employment dislocation of 596.2 thousand person-years is quite similar to the unilateral scenario 1 . The effects on U.S. exports and imports are, however, quite different. Exports decline more significantly, $\$ 1,531.0$ million, while imports increase by $\$ 427.2$ million. The response of imports and exports is partially due to the larger appreciation of the dollar.

At the sectoral level, the direction of change in employment remains the same, but the magnitudes are different. Within traded goods, the declines in employment are now larger and the increases in employment are smaller. There is an increase in the amount of labor (155.2 thousand person-years) shifted from traded to nontraded industries due primarily to the larger reduction in exports.

The reduction in exports reflects the dollar appreciation and a decline in world prices. Global defense spending is primarily focused on the purchase of goods that are traded internationally, especially durable goods and basic metal industries. The

\footnotetext{
${ }^{19}$ See Grobar and Stern (1989) and Grobar, Stern, and Deardorff (1990) for further details and estimates and analysis of the economic effects of international trade in armaments for 1980.
} 
multilateral reduction in defense spending thus reduces the world demand for traded goods. This reduced demand is then translated into lower world prices. In response to the lower prices, domestic producers shift away from export production to home production, thereby reducing exports.

The sectoral results for imports, partition 4 of Table 9 , to the extent that they differ from those of the unilateral simulations, also reflect the lower world prices. Imports increase in 17 of the 22 sectors. Sectors with a decline in imports experience a smaller decline and conversely for sectors with a rise in imports. Recall that ISIC 384 was responsible for the bulk of the reduction in imports in the unilateral runs. The multilateral scenario produces a greater decline in the world price for sector 384 , and consequently reduces the decline in imports by approximately $25 \%$.

In the aggregate, a multilateral reduction in military spending thus appears to have a somewhat larger impact on the U.S. economy than does a unilateral reduction. At the sectoral level, while some industries may experience a larger impact, the differences appear to be fairly small.

\section{Conclusions and Implications}

In the long run, a reduction in defense spending is generally regarded to have a positive impact on an economy. In the short run, however, a reduction in defense outlays could result in unemployment and adjustment pressures in at least some sectors of the economy. In order to facilitate a smooth transition, government assistance, if deemed necessary, should be pointed in the right direction. The CGE results that we have reported based on the Michigan Model are useful in assessing the sectoral impact of a reduction in military expenditures.

While it is not entirely under the control of government, it may be possible to influence whether nondefense government, consumption, or investment spending expands in response to reductions in military spending. The decision of which policy to follow is largely outside the scope of this paper. That is, whether reduced military spending is used 
to meet other federal spending needs, to reduce taxes allowing for higher consumption or personal savings, or to cut the federal deficit resulting in higher domestic investment, must be decided on the basis of many considerations not discussed here.

While the impacts of a $25 \%$ unilateral or multilateral reduction in military expenditures do not appear to be large in the aggregate, our computational results suggest that the sectoral impacts differ significantly depending on the accompanying macroeconomic policy. It also appears that certain specific sectors may bear the brunt of the adjustment costs and therefore would be in need of assistance in the event that reduced military spending may in fact be carried out. 


\section{References}

Deardorff, Alan V. and Robert M. Stern. 1986. The Michigan Model of World Production and Trade: Theory and Applications. Cambridge, MA: MIT Press.

Deardorff, Alan V. and Robert M. Stern. 1990. Computational Analysis of Global Trading Arrangements. Ann Arbor, MI: University of Michigan Press.

Dunne, J. Paul and Ron P. Smith. 1984. "The Economic Consequences of Reduced UK Military Expenditure," Cambridge Journal of Economics 8: 297-310.

Grobar, Lisa M. and Robert M. Stern. 1989. "A Data Set on International Trade in Armaments for the Western Industrialized and Developing Countries for 1980: Sources and Methodological Issues,", Weltwirtschaftliches Archiv 125: 748-762.

Grobar, Lisa M., Robert M. Stern, and Alan V. Deardorff. 1990. "The Economic Effects of International Trade in Armaments in the Major Western Industrialized and Developing Countries," Defence Economics 1: 97-120.

Liew, L.H. 1985. "The Impact of Defence Spending on the Australian Economy," Australian Economic Papers 24: 326-36.

Leontief, Wassily W., and Marvin Hoffenberg. 1961. "The Economic Effects of Disarmament," Scientific American 204.

Leontief, Wassily W., Alison Morgan, Karen Polenske, David Simpson, and Edward Tower. 1965. "The Economic Impact-Industrial and Regional-of an Arms Cut," The Review of Economics and Statistics 47.

Stern, Robert M., Jonathan Francis, and Bruce F. Schumacher. 1976. Price Elasticities in International Trade. London: Macmillan Press.

Steuerle, Eugene C. and Susan Wiener. 1990. "Spending the Peace Dividend: Lessons From History," Urban Institute Policy Paper.

United Nations. Yearbook of International Trade Statistics.

United States Arms Control and Disarmament Agency. 1988. World Military Expenditures and Arms Transfers 1987. U.S. Government Printing Office.

United States Congressional Budget Office. 1990. Summary of the Economic Effects of Reduced Defense Spending. CBO Staff Memorandum.

Zarembka, Paul and Helen Chernicoff. 1973. "Further Results on the Empirical Relevance of the CES Production Function." Review of Economics and Statistics 53: 106-10. 
Table 1

Changes in the Composition of Postwar Government Spending

\begin{tabular}{|l|c|ccc|}
\hline & \multicolumn{4}{|c|}{ Change in Percent of GNP } \\
\cline { 2 - 5 } Period & $\begin{array}{c}\text { Military } \\
\text { Expenditures } \\
(1)\end{array}$ & $\begin{array}{c}\text { Human } \\
\text { Resources } \\
\text { Spending } \\
(2)\end{array}$ & $\begin{array}{c}\text { Government } \\
\text { Receipts } \\
(3)\end{array}$ & $\begin{array}{c}\text { Government } \\
\text { Deficit } \\
(4)\end{array}$ \\
\hline $\begin{array}{l}\text { WWII } \\
1945-48\end{array}$ & -35.4 & 3.1 & -4.5 & -27.1 \\
$\begin{array}{c}\text { Korean War } \\
1953-58\end{array}$ & -4.0 & 1.7 & -1.4 & -1.2 \\
$\begin{array}{c}\text { Vietnam War } \\
1968-73\end{array}$ & -3.6 & 2.3 & 0.0 & -1.8 \\
$\begin{array}{c}\text { Recent } \\
1986-89\end{array}$ & -0.6 & -0.5 & 0.8 & -2.3 \\
\hline
\end{tabular}

Source: Steuerle and Wiener (1990).

b. After Redistribution

\begin{tabular}{ccc|c|r|r|}
\multicolumn{7}{c}{} & \multicolumn{4}{c}{$\begin{array}{c}\text { Total } \\
\text { Final } \\
\text { Demand } \\
\text { Sector }\end{array}$} & $\begin{array}{c}\text { Defense } \\
(1)\end{array}$ & $\begin{array}{c}\text { Other } \\
(2)\end{array}$ & $\begin{array}{c}\alpha \\
(3)\end{array}$ & \multicolumn{1}{c|}{$\begin{array}{c}\text { e } \alpha \\
(5)\end{array}$} \\
\cline { 2 - 7 } 1. & 75 & 375 & 450 & .38 & .15 \\
2. & 225 & 125 & 350 & .29 & -.12 \\
3. & 150 & 250 & 400 & .33 & .00 \\
\cline { 2 - 7 } Total & 450 & 750 & 1200 & 1.00 & \\
\cline { 2 - 7 } & & & & &
\end{tabular}


Table 2

Sources of Final Demand

(Millions of $\$ 1985$ )

\begin{tabular}{|c|c|c|c|c|c|c|c|}
\hline Industry & (ISIC) & Defense & Consumption & Investment & $\begin{array}{l}\text { Government } \\
\text { (Nondefense) }\end{array}$ & $\begin{array}{c}\text { Total } \\
\text { Civilian }\end{array}$ & Total \\
\hline \multicolumn{8}{|l|}{ Traded Goods } \\
\hline Agr., For., \& Fishing & $(1)$ & 12 & 21252 & 0 & 11972 & 33224 & 33236 \\
\hline Food, Bev., \& Tobacco & (310) & 179 & 202207 & 0 & 7102 & 209309 & 209488 \\
\hline Textiles & $(321)$ & 50 & 6282 & 1566 & 410 & 8258 & 8308 \\
\hline Wearing Apparel & (322) & 821 & 63663 & 0 & 1007 & 64670 & 65491 \\
\hline Leather Products & (323) & 17 & 3237 & 0 & 39 & 3276 & 3293 \\
\hline Footwear & $(324)$ & 18 & 8683 & 0 & 41 & 8724 & 8742 \\
\hline Wood Products & (331) & 35 & 865 & 15 & 157 & 1037 & 1072 \\
\hline Furniture \& Fixtures & (332) & 50 & 16635 & 12768 & 1981 & 31384 & 31434 \\
\hline Paper \& Paper Products & (341) & 106 & 11739 & 0 & 2878 & 14617 & 14723 \\
\hline Printing \& Publishing & (342) & 318 & 22471 & 0 & 7580 & 30051 & 30369 \\
\hline Chemicals & $(35 A)$ & 2281 & 39146 & 769 & 6622 & 46537 & 48818 \\
\hline Petrol. \& Rel. Prod. & (35B) & 4595 & 67477 & 0 & 10049 & 7.7526 & 82121 \\
\hline Rubber Products & (355) & 544 & 10202 & 94 & 1438 & 11734 & 12278 \\
\hline Nonmetallic Min. Prod. & $(36 A)$ & 52 & 1907 & 0 & 238 & 2145 & 2197 \\
\hline Glass \& Glass Products & (362) & 17 & 1135 & 0 & 679 & 1814 & 1831 \\
\hline Iron \& Stee 1 & $(371)$ & 205 & 8 & 221 & 97 & 326 & 531 \\
\hline Nonferrous Metals & $(372)$ & 346 & 54 & 89 & 339 & 482 & 828 \\
\hline Metal Products & (381) & 3849 & 4865 & 6369 & 1208 & 12442 & 16291 \\
\hline Nonelectric Machinery & $(382)$ & 11071 & 8091 & 103977 & 5271 & 117340 & 128411 \\
\hline Electric Machinery & $\begin{array}{l}(383) \\
(384)\end{array}$ & $\begin{array}{l}23888 \\
56805\end{array}$ & $\begin{array}{l}32339 \\
97882\end{array}$ & $\begin{array}{l}49766 \\
78130\end{array}$ & $\begin{array}{l}4050 \\
8079\end{array}$ & $\begin{array}{r}86155 \\
184091\end{array}$ & $\begin{array}{l}110043 \\
240895\end{array}$ \\
\hline Miscellaneous Manufac. & $(38 \mathrm{~A})$ & $\begin{array}{r}56805 \\
8947\end{array}$ & 33538 & 24220 & 6940 & 64698 & 73645 \\
\hline Total Traded & & 114206 & 653678 & 277984 & 78177 & 1009839 & 1124045 \\
\hline \multicolumn{8}{|l|}{ Nontraded Goods } \\
\hline Mining \& Quarrying & 2) & 59 & 294 & 916 & 1532 & 2742 & 2801 \\
\hline Electric, Gas \& Water & & 2235 & 99563 & 0 & 14112 & 113675 & 115910 \\
\hline Construction & 5) & 13754 & $\begin{array}{r}0 \\
0\end{array}$ & 314657 & 88217 & 402874 & 416628 \\
\hline Wholesale \& Ret. Trade & 6) & 7482 & 637457 & 46718 & 4463 & 688638 & 696120 \\
\hline Transp., Stor., \& Com. & 7) & 7733 & 111161 & 7772 & 13139 & 132072 & 139805 \\
\hline Fin., Ins. \& Real Est. & 8) & 12889 & 585737 & 16900 & 40135 & 642772 & 655661 \\
\hline Comm., Soc. \&Pers.Serv. & ( 9) & 100788 & 522687 & 0 & 321843 & 844530 & 945318 \\
\hline Total Nontraded & & 144940 & 1956899 & 386963 & 483441 & 2827303 & 2972243 \\
\hline Total, All Industries & & 259146 & 2610577 & 664947 & 561618 & 3837142 & 4096288 \\
\hline
\end{tabular}

Source: 1985 United States Input-Output table. Survey of Current Business, January 1990. 


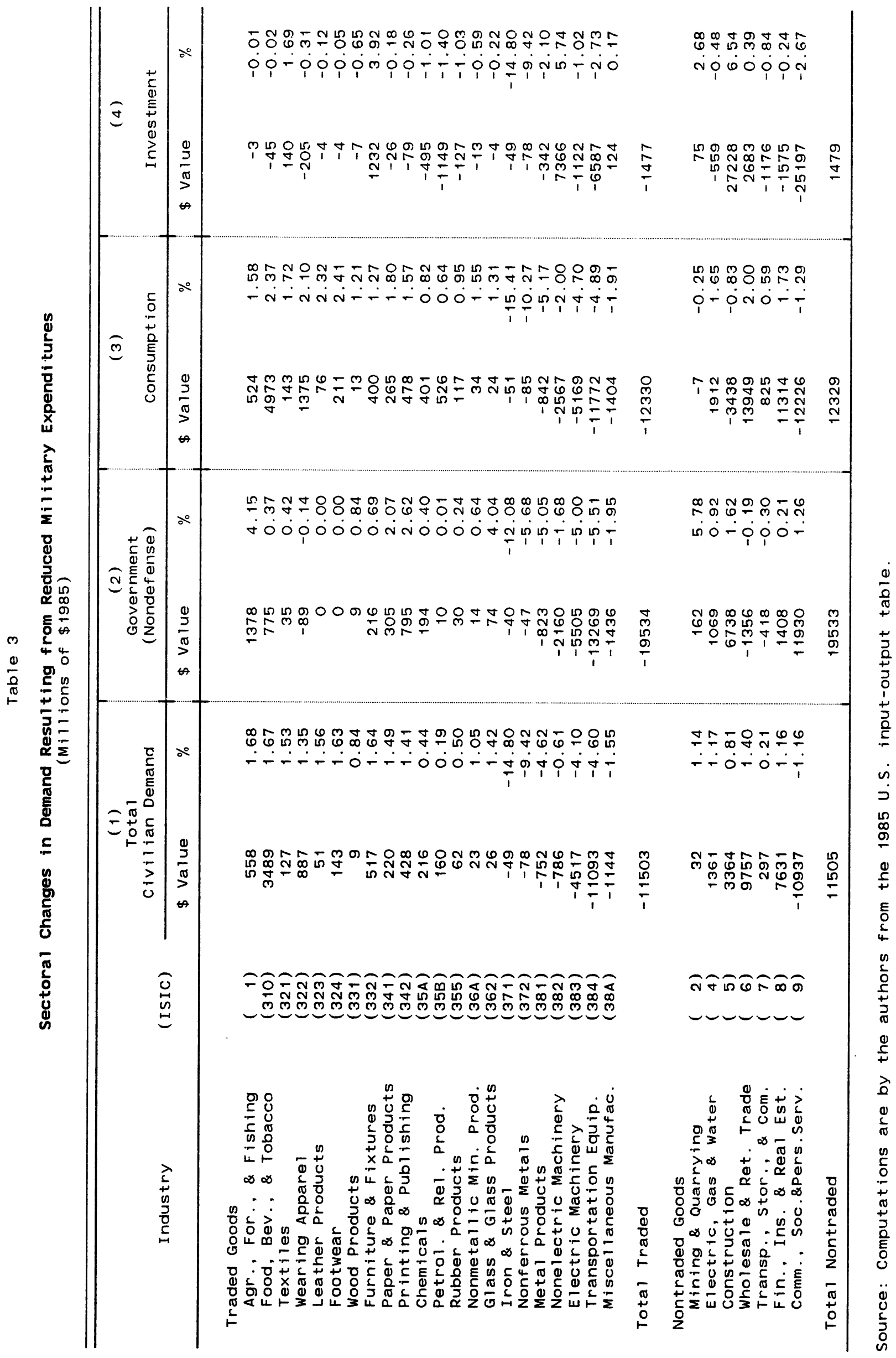


Table 4

Assumed Redistribution of $\$ 150$ Million

from Defense to Other Spending

a. Original Distribution

\begin{tabular}{rcc|c|c|}
\multicolumn{3}{c}{} & \multicolumn{3}{c}{$\begin{array}{c}\text { Total } \\
\text { Final } \\
\text { Semand } \\
\end{array}$} & $\begin{array}{c}\text { Defense } \\
(1)\end{array}$ & $\begin{array}{c}\text { Other } \\
(2)\end{array}$ & $\begin{array}{c}\alpha \\
(3)\end{array}$ \\
\cline { 3 - 5 } 1. & 100 & 300 & 400 & .33 \\
2. & 300 & 100 & 400 & .33 \\
3. & 200 & 200 & 400 & .33 \\
\cline { 2 - 5 } Total & 600 & 600 & 1200 & 1.00 \\
\cline { 2 - 5 } & & & &
\end{tabular}


Table 5

Summary of Effects on the United States

Due to Shifts of 25\% in Defense Spending

\begin{tabular}{|c|c|c|c|c|c|}
\hline & $\begin{array}{c}\text { Total } \\
\text { Civilian Demand } \\
\text { (1) }\end{array}$ & $\begin{array}{c}\text { Nondefense } \\
\text { Government } \\
\text { (2) }\end{array}$ & $\begin{array}{c}\text { Consumption } \\
\text { (3) }\end{array}$ & $\begin{array}{c}\text { Investment } \\
\text { (4) }\end{array}$ & $\begin{array}{c}\text { Multilateral } \\
\text { Demilitarization } \\
\text { (5) }\end{array}$ \\
\hline \multicolumn{6}{|l|}{ Change in Exports } \\
\hline Value (\$ Mill.) & -380.4 & -1197.9 & -887.8 & 2303.1 & -1531.0 \\
\hline Percent & -0.2 & -0.6 & -0.4 & 1.1 & -0.7 \\
\hline \multicolumn{6}{|l|}{ Change in Imports } \\
\hline Value (\$ Mill.) & -169.3 & -912.0 & -663.5 & 2398.9 & 427.2 \\
\hline Percent & -0.1 & -0.5 & -0.4 & 1.3 & 0.2 \\
\hline \multicolumn{6}{|l|}{ Labor Dislocations* } \\
\hline '000 Person-Years & 575.6 & 456.7 & 734.5 & 808.2 & 596.2 \\
\hline Percent & 0.6 & 0.5 & 0.7 & 0.8 & 0.6 \\
\hline \multicolumn{6}{|l|}{ Percent Change in: } \\
\hline Terms of Trade & 0.05 & 0.07 & 0.05 & 0.02 & 0.12 \\
\hline Effective Exchange Rate\# & 0.1 & 0.1 & 0.1 & -0.2 & 0.2 \\
\hline Prices + & 0.1 & 0.1 & 0.1 & -0.1 & 0.2 \\
\hline
\end{tabular}

* Refers to the sum of positive changes in home and export sectors within all industries.

\#Positive = Appreciation.

+ Index of import and home prices. 


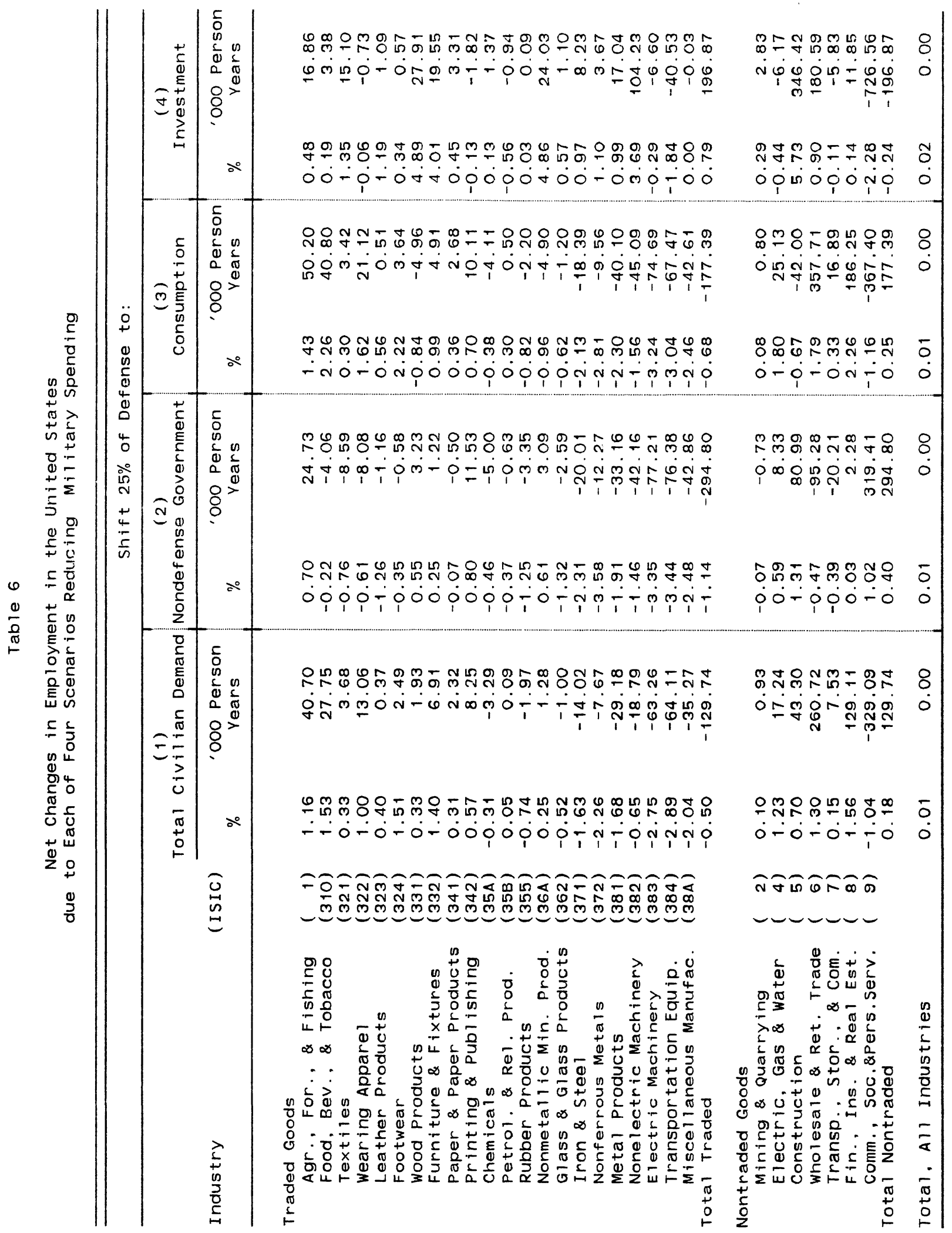


Table 7

Net Percentage Changes in Trade in the United States due to Each of Four Scenarios

Reducing Military Spending

\begin{tabular}{|c|c|c|c|c|c|c|c|c|c|}
\hline \multirow{3}{*}{ Industry } & \multirow{3}{*}{ ( ISIC) } & \multicolumn{8}{|c|}{ Shift $25 \%$ of Defense to: } \\
\hline & & \multicolumn{2}{|c|}{$\begin{array}{c}(1) \\
\text { Total Civilian Demand }\end{array}$} & \multicolumn{2}{|c|}{$\begin{array}{c}\text { (2) } \\
\text { Nondefense Government }\end{array}$} & \multicolumn{2}{|c|}{$\begin{array}{c}\text { (3) } \\
\text { Consumption }\end{array}$} & \multicolumn{2}{|c|}{$\begin{array}{l}\text { (4) } \\
\text { Investment }\end{array}$} \\
\hline & & Exports & Imports & Exports & Imports & Exports & Imports & Exports & Imports \\
\hline \multicolumn{10}{|l|}{ Traded Goods } \\
\hline $\begin{array}{l}\text { Agr., For., \& Fishing } \\
\text { Food, Bev., \& Tobacco } \\
\text { Textiles } \\
\text { Wearing Apparel } \\
\text { Leather Products } \\
\text { Footwear } \\
\text { Wood Products } \\
\text { Furniture \& Fixtures } \\
\text { Paper \& Paper Products } \\
\text { Printing \& Publishing } \\
\text { Chemicals } \\
\text { Petrol. \& Rel. Prod. } \\
\text { Rubber Products } \\
\text { Nonmetallic Min. Prod. } \\
\text { Glass \& Glass Products } \\
\text { Iron \& Steel } \\
\text { Nonferrous Metals } \\
\text { Metal Products } \\
\text { Nonelectric Machinery } \\
\text { Electric Machinery } \\
\text { Transportation Equip. } \\
\text { Miscellaneous Manufac. }\end{array}$ & 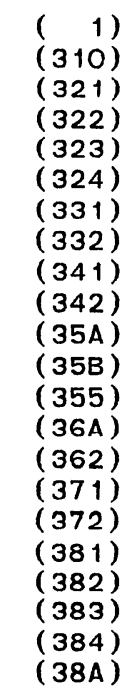 & $\begin{array}{r}0.02 \\
-1.35 \\
-1.28 \\
-1.08 \\
-1.61 \\
0.18 \\
-0.53 \\
-0.16 \\
0.06 \\
-0.13 \\
-0.05 \\
-0.15 \\
-0.27 \\
-0.26 \\
-0.23 \\
-0.51 \\
-0.34 \\
-0.02 \\
0.21 \\
-0.21 \\
-0.16 \\
-0.04\end{array}$ & $\begin{array}{r}2.96 \\
2.13 \\
1.35 \\
2.98 \\
2.95 \\
2.52 \\
0.98 \\
3.39 \\
2.05 \\
2.30 \\
1.42 \\
1.11 \\
1.15 \\
2.09 \\
1.50 \\
-0.68 \\
-0.56 \\
-0.51 \\
0.88 \\
-1.73 \\
-4.35 \\
0.09\end{array}$ & $\begin{array}{l}0.11 \\
-1.39 \\
-2.09 \\
-4.35 \\
-3.80 \\
-3.12 \\
-0.83 \\
-1.57 \\
-0.82 \\
-0.73 \\
-0.36 \\
-0.48 \\
-0.97 \\
-0.96 \\
-0.73 \\
-1.37 \\
-0.25 \\
-0.71 \\
-0.35 \\
-0.94 \\
-0.54 \\
-0.38\end{array}$ & $\begin{array}{r}4.86 \\
0.46 \\
0.23 \\
0.49 \\
0.10 \\
0.22 \\
1.16 \\
1.65 \\
2.59 \\
4.05 \\
1.52 \\
0.98 \\
0.97 \\
2.44 \\
4.00 \\
1.61 \\
2.79 \\
-0.70 \\
-0.82 \\
-2.96 \\
-5.74 \\
-0.27\end{array}$ & $\begin{array}{l}-0.01 \\
-1.84 \\
-2.02 \\
-1.71 \\
-2.61 \\
-0.17 \\
-0.55 \\
-0.49 \\
-0.13 \\
-0.42 \\
-0.20 \\
-0.27 \\
-0.52 \\
-0.51 \\
-0.51 \\
-1.18 \\
-1.30 \\
-0.30 \\
-0.08 \\
-0.57 \\
-0.25 \\
-0.19\end{array}$ & $\begin{array}{r}3.27 \\
3.05 \\
1.55 \\
4.53 \\
4.38 \\
3.76 \\
0.71 \\
2.67 \\
2.46 \\
2.74 \\
1.89 \\
1.55 \\
1.90 \\
1.58 \\
1.44 \\
-1.59 \\
-1.74 \\
-1.46 \\
-1.39 \\
-2.72 \\
-4.79 \\
-0.46\end{array}$ & $\begin{array}{r}0.08 \\
0.67 \\
2.37 \\
4.33 \\
4.41 \\
4.48 \\
-0.19 \\
2.37 \\
1.57 \\
1.55 \\
0.78 \\
0.62 \\
1.33 \\
1.34 \\
1.28 \\
2.93 \\
3.46 \\
1.68 \\
1.81 \\
1.85 \\
0.55 \\
0.84\end{array}$ & $\begin{array}{r}0.21 \\
-0.05 \\
1.50 \\
-0.85 \\
-0.12 \\
-0.33 \\
1.91 \\
7.81 \\
-0.02 \\
-0.87 \\
-0.49 \\
-0.46 \\
-1.58 \\
3.83 \\
-0.30 \\
0.98 \\
1.33 \\
3.45 \\
11.87 \\
3.36 \\
-1.42 \\
2.61\end{array}$ \\
\hline Total Traded & & -0.19 & -0.07 & -0.58 & -0.47 & -0.43 & -0.33 & 1.14 & 1.41 \\
\hline
\end{tabular}


Table 9

Comparison of Unilateral and Multilateral

Results for the United States

\begin{tabular}{|c|c|c|c|c|c|c|c|c|c|}
\hline \multirow{2}{*}{ Industry } & \multirow{2}{*}{ ( ISIC) } & \multicolumn{2}{|c|}{$\begin{array}{l}\text { Employment } \\
\text { Percent Change }\end{array}$} & \multicolumn{2}{|c|}{$\begin{array}{c}\text { Employment } \\
\text { Ooo Person-years }\end{array}$} & \multicolumn{2}{|c|}{$\begin{array}{l}\text { Exports } \\
\text { Percent Change }\end{array}$} & \multicolumn{2}{|c|}{$\begin{array}{l}\text { Imports } \\
\text { Percent Change }\end{array}$} \\
\hline & & Unilateral & Multilateral & Unilateral & Multilateral & Unilateral & Multilateral & Unilateral & Multilateral \\
\hline \multicolumn{10}{|l|}{ Traded Goods } \\
\hline Agr., For., \& Fishing & $(1)$ & 1.16 & 1.50 & 40.70 & 52.50 & 0.02 & 0.20 & 2.96 & 2.67 \\
\hline Food, Bev., \& Tobacco & $(310)$ & 1.53 & 1.61 & 27.75 & 29.24 & -1.35 & -0.79 & 2.13 & 2.05 \\
\hline Textiles & (321) & 0.33 & 0.22 & 3.68 & 2.51 & -1.28 & -1.53 & 1.35 & 1.33 \\
\hline Wearing Apparel & $(322)$ & 1.00 & 0.86 & 13.06 & 11.21 & -1.08 & -4.06 & 2.98 & 3.45 \\
\hline Leather Products & (323) & 0.40 & 0.15 & 0.37 & 0.14 & -1.61 & -2.65 & 2.95 & 3.02 \\
\hline Footwear & (324) & 1.51 & 1.53 & 2.49 & 2.52 & 0.18 & -0.51 & 2.52 & 2.62 \\
\hline Wood Products & (331) & 0.33 & 0.32 & 1.93 & 1.84 & -0.53 & -0.52 & 0.98 & 0.97 \\
\hline Furniture \& Fixtures & (332) & 1.40 & 1.39 & 6.91 & 6.84 & -0.16 & -0.81 & 3.39 & 3.63 \\
\hline Paper \& Paper Products & $(341)$ & 0.31 & 0.01 & 2.32 & 0.06 & 0.06 & -1.88 & 2.05 & 2.27 \\
\hline Printing \& Publishing & $(342)$ & 0.57 & 0.54 & 8.25 & 7.73 & -0.13 & -1.08 & 2.30 & 2.74 \\
\hline Chemicals & $(35 A)$ & -0.31 & -0.43 & -3.29 & -4.68 & -0.05 & -0.33 & 1.42 & 1.57 \\
\hline Petrol. \& Rel. Prod. & (35B) & 0.05 & 0.04 & 0.09 & 0.06 & -0.15 & -0.66 & 1.11 & 1.32 \\
\hline Rubber Products & (355) & -0.74 & -1.14 & -1.97 & -3.04 & -0.27 & -1.28 & 1.15 & 1.89 \\
\hline Nonmetallic Min. Prod. & $(36 A)$ & 0.25 & 0.18 & 1.28 & 0.91 & -0.26 & -0.96 & 2.09 & 2.43 \\
\hline Glass \& Glass Products & (362) & -0.52 & -0.97 & -1.00 & -1.90 & -0.23 & -1.16 & 1.50 & 1.67 \\
\hline Iron \& Steel & (371) & -1.63 & -1.92 & -14.02 & -16.61 & -0.51 & -2.28 & -0.68 & -0.65 \\
\hline Nonferrous Metals & (372) & -2.26 & -2.88 & -7.67 & -9.82 & -0.34 & -2.13 & -0.56 & -0.65 \\
\hline Metal Products & $(381)$ & -1.68 & -1.85 & -29.18 & -32.17 & -0.02 & -0.89 & -0.51 & -0.14 \\
\hline Nonelectric Machinery & (382) & -0.65 & -0.84 & -18.79 & -24.13 & 0.21 & -0.45 & 0.88 & 1.01 \\
\hline Electric Machinery & (383) & -2.75 & -3.03 & -63.26 & -69.67 & -0.21 & -1.77 & -1.73 & -1.16 \\
\hline Transportation Equip. & $(384)$ & -2.89 & -3.21 & $-64 \cdot 11$ & -71.27 & -0.16 & -1.15 & -4.35 & -3.22 \\
\hline Miscellaneous Manufac. & $(38 A)$ & -2.04 & -2.17 & -35.27 & -37.47 & -0.04 & -0.19 & 0.09 & 0.19 \\
\hline Total Traded & & -0.50 & -0.59 & -129.74 & -155.19 & -0.19 & -0.74 & -0.07 & 0.26 \\
\hline \multicolumn{10}{|l|}{ Nontraded Goods } \\
\hline Mining \& Quarrying & & 0.10 & 0.01 & 0.93 & 0.07 & & & & \\
\hline Electric, Gas \& Water & 4) & 1.23 & 1.23 & 17.24 & 17.22 & & & & \\
\hline Construction & 5) & 0.70 & 0.75 & 43.30 & 46.15 & & & & \\
\hline Wholesale \& Ret. Trade & 6) & 1.30 & 1.32 & 260.72 & 265.77 & & & & \\
\hline Transp., Stor., \& Com. & 7) & 0.15 & 0.16 & 7.53 & 7.97 & & & & \\
\hline Fin., Ins. \& Real Est. & 8) & 1.56 & 1.61 & 129.11 & 133.57 & & & & \\
\hline Comm. , Soc.\&Pers.Serv. & 9) & -1.04 & -0.99 & -329.09 & -315.56 & & & & \\
\hline Total Nontraded & & 0.18 & 0.22 & 129.74 & 155.19 & & & & \\
\hline
\end{tabular}



Summary of Effects on the Major Industrialized

and Developing Countries due to

a $25 \%$ Multilateral Reduction in Military Expenditures

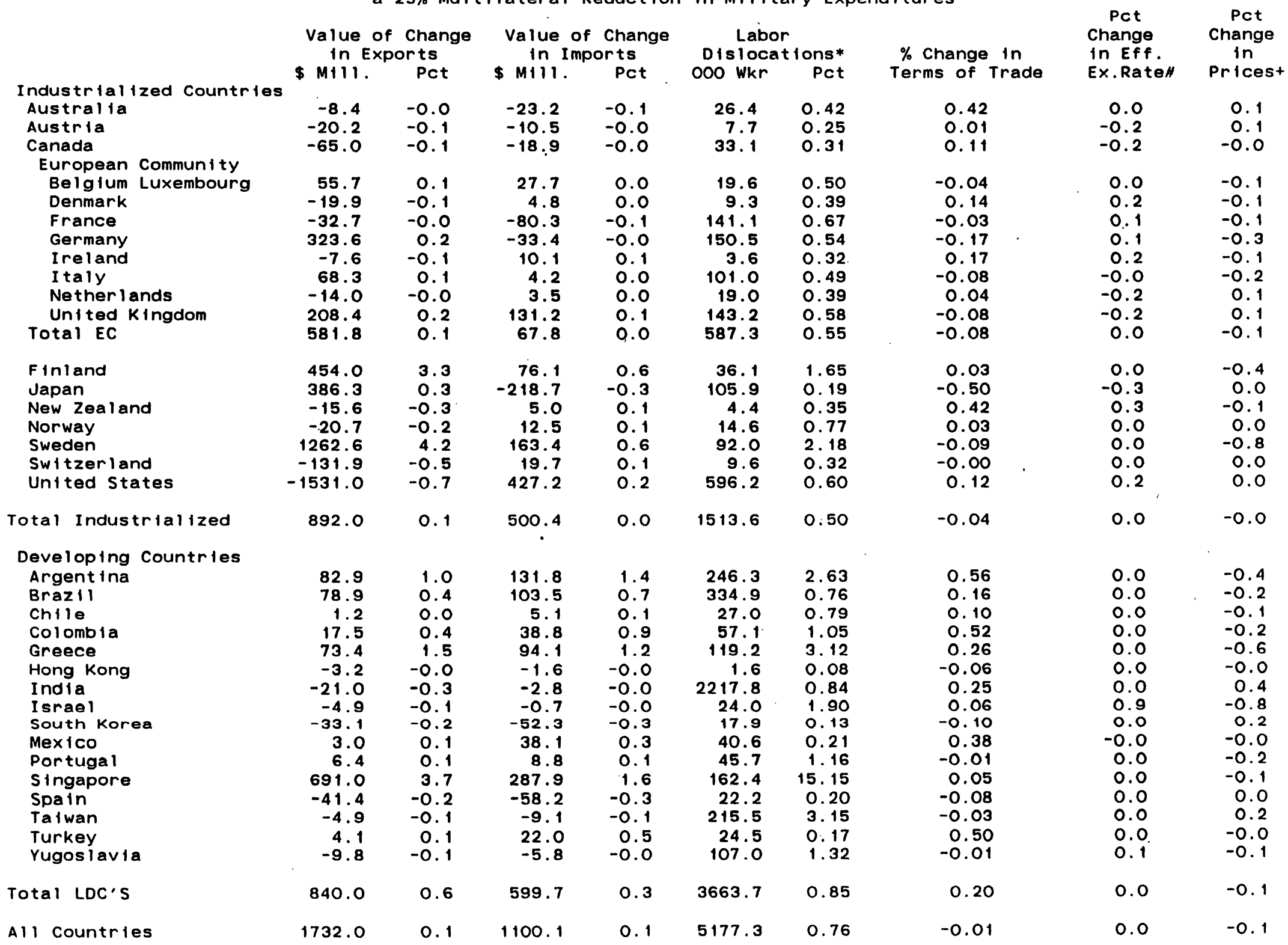

* Refers to the sum of positive changes in home and export sectors within all industries.

HPOSitive = Appreciation.

I Index of import and home prices. 
Figure 1

Partial Equilibrium Determination of Home-Sector prices and Quantities and of Exports and Imports
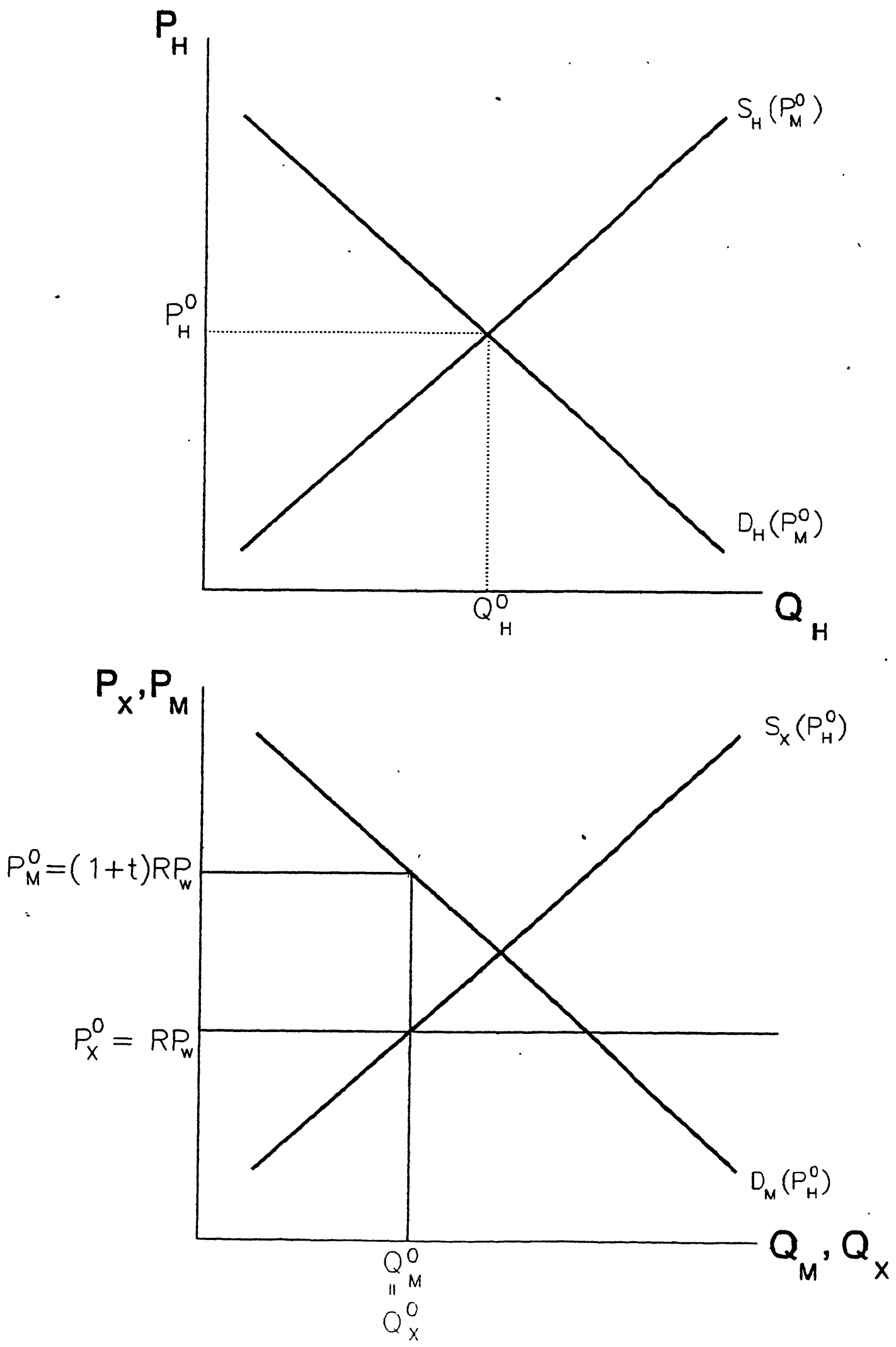


\section{Figure 2}

Partial Equilibrium Effects of a Cut in Defense Spending in an Industry where Demand Increases

$P_{H}$
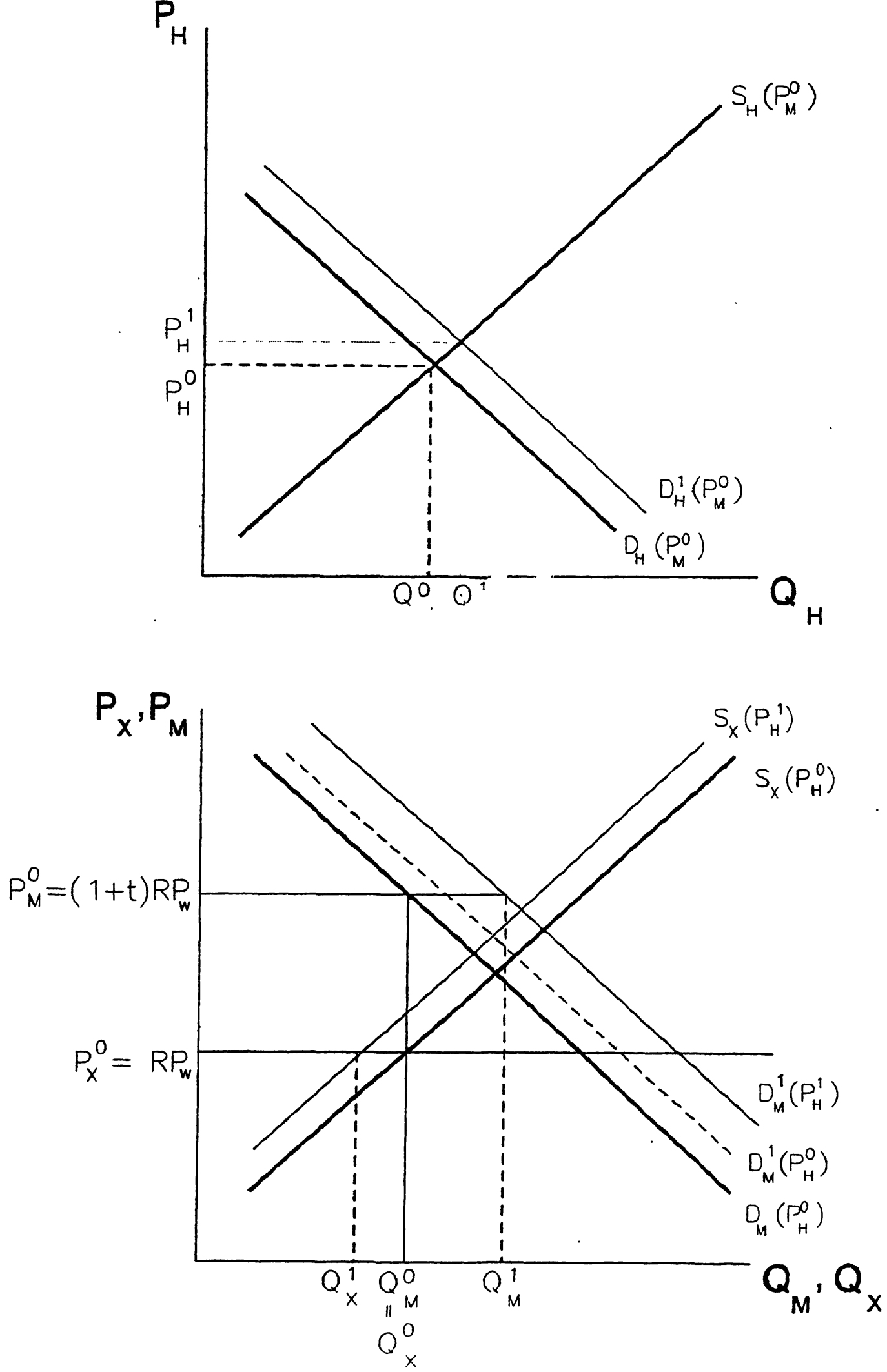
Figure 3

Partial Equilibrium Effects of a Cut in Defense Spending in an Industry where Demand Decreases
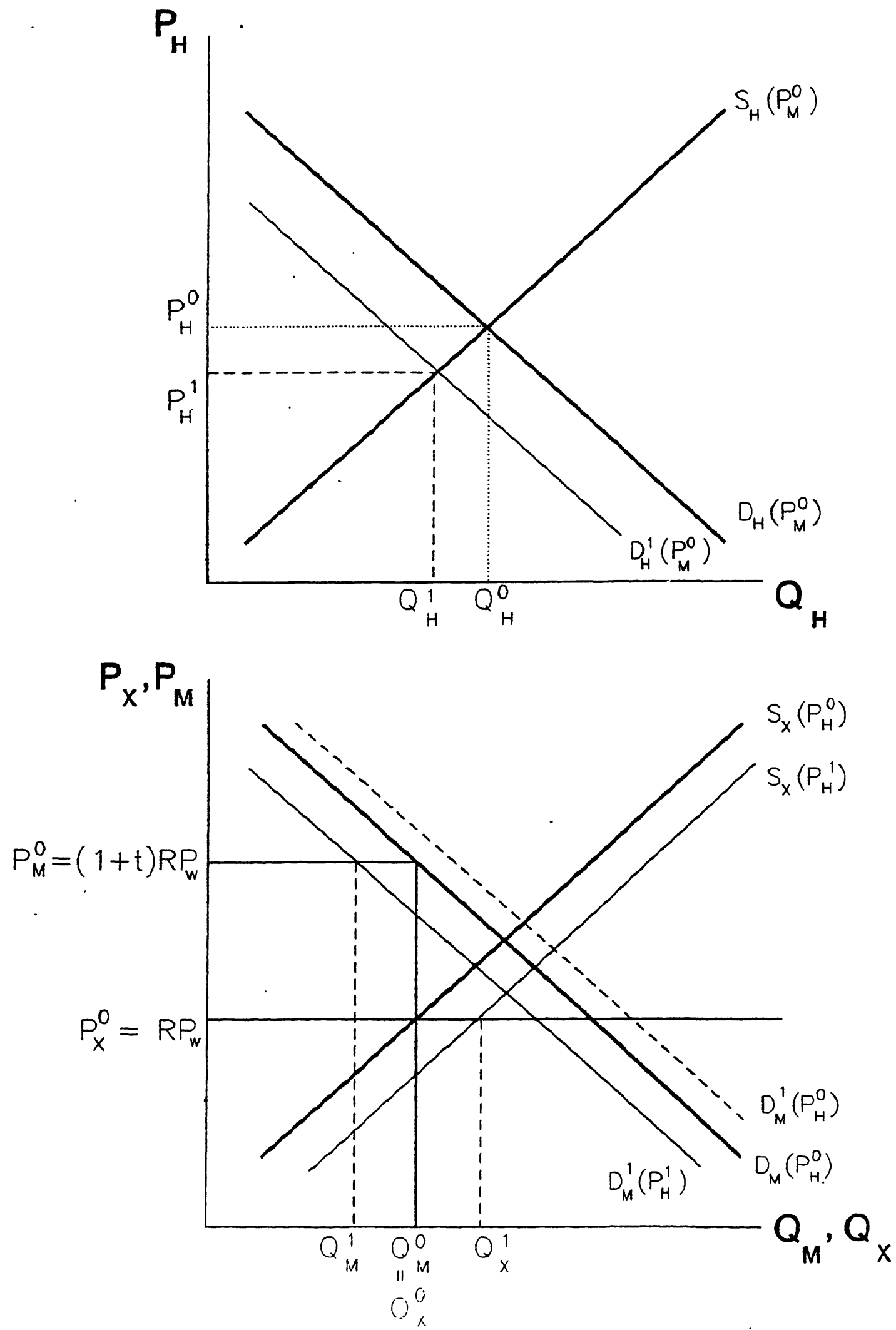